\title{
ATRIAL FIBRILLATION IN PATIENT WITH DIABETES MELLITUS 2 TYPE: CO-EXISTANCE AND THERAPEUTIC APROCHES
}

\author{
Makharynska O. S. ${ }^{1}$, Fagbemi Oluwatoyin O. ${ }^{1}$, Doroshenko O. V. ${ }^{2}$, Pozhar V. I. ${ }^{2}$ \\ ${ }^{1}$ V. N. Karazin Kharkiv National University, Kharkiv, Ukraine \\ ${ }^{2}$ Kharkiv Medical Academy of Postgraduate Education, Kharkiv, Ukraine
}

On the example of the clinical case of atrial fibrillation in patient with diabetes mellitus type 2, were discussed molecular mechanisms and therapeutic perspectives, anticoagulation treatment and anti-arrhythmic treatment strategies benefit. Recommendations on lifestyle modification and medicament treatment tactics are described.

KEY WORDS: diabetes mellitus, atrial fibrillation, anticoagulation, correlation

\section{ФИБРІЛЯЦІЯ ПЕРЕДСЕРДЬ У ХВОРОГО НА ЦУКРОВИЙ ДІАБЕТ 2 ТИПУ: СПІВІСНУВАННЯ ТА ТЕРАПЕВТИЧНІ МОЖЛИВОСТІ}

\author{
Махаринська О. С. ${ }^{1}$, Фагбемі Олуватойін О. ${ }^{1}$, Дорошенко О. В. ${ }^{2}$, Пожар В. Й. ${ }^{2}$ \\ ${ }^{1}$ Харківський національний університет імені В. Н. Каразіна, м. Харків, Україна \\ ${ }^{2}$ Харківська Медична Академія Післядипломної Освіти, м. Харків, Україна
}

На прикладі клінічного випадку вперше діагностованої миготливої аритмії у хворого на цукрово1 діабет 2 типу обговорили молекулярні механізми та терапевтичні перспективи антикоагулянтної терапії та стратегії антиаритмічної терапії. Описано рекомендації з модифікації способу життя і тактики лікування.

КЛЮЧОВІ СЛОВА: цукровий діабет, миготлива аритмія, антикоагулянтна терапія, кореляція

\section{ФИБРИЛЛЯЦИЯ ПРЕДСЕРДИЙ У ПАЦИЕНТА С САХАРНЫМ ДИАБЕТОМ 2 ТИПА: СОСУЩЕСТВОВАНИЕ И ТЕРАПЕВТИЧЕСКИЕ ВОЗМОЖНОСТИ}

Махаринская Е. С. ${ }^{1}$, Фагбеми Олуватойин О. ${ }^{1}$, Дорошенко О. В. ${ }^{2}$, Пожар В. И. ${ }^{2}$

${ }^{1}$ Харьковский национальный университет имени В. Н. Каразина, г. Харьков, Украина

${ }^{2}$ Харьковская Медицинская Академия Последипломного Образования, г. Харьков, Украина

На примере клинического случая впервые диагностированной фибрилляции предсердий у пациента с сахарным диабетом 2 типа обсудили молекулярные механизмы и терапевтические перспективы антикоагулянтной терапии и стратегии антиаритмической терапии. Описаны рекомендации по модификации образа жизни и тактике лечения.

КЛЮЧЕВЫЕ СЛОВА: сахарный диабет, мерцательная аритмия, антикоагулянтная терапия, корреляция

\section{INTRODUCTION}

One of the most frequent cardiac arrhythmias in therapeutic practice is atrial fibrillation (AF). This type of arrhythmias is associated with increased cardiovascular and cerebrovascular complication's risk and mortality. Despite, the relationship between diabetes and $\mathrm{AF}$ is unclear [1], nowadays medical world focuses mostly on increased risk of thromboembolic events in patients with co-existed $\mathrm{AF}$ and $\mathrm{DM}$ but there are significant evidences of an increased $\mathrm{AF}$ prevalence in patients with diabetes. Insulin resistance, impaired glucose tolerance, immunity alternations with hypercoagulability, increased angiogenesis and extracellular matrix turnover in patients with diabetes mellitus (DM) as a result will lead to possible endothelial dysfunction, abnormal activation of the reninangiotensin-aldosterone system and pathological atherogenesis, as AF appearance 
factors [2]. Also the mail triggers in $\mathrm{AF}$ occurrence can be remodeling of the left atrium, atrial dilatation and interstitial fibrosis seen in patients with diabetes [3]. Some studies in patients with diabetes and impaired glucose tolerance with treatment approach of radiofrequency ablation for paroxysmal $\mathrm{AF}$ have shown significantly decreased right and left atria voltages due to atrial electrical remodeling and atrial fibrosis [4]. The influence of diabetes on the autonomic nervous system sympathetic and parasym-pathetic - leads to increased uptake choline and release acetylcholine with shortened atrial effective refractory period and increased dispersion [5-6]. Not all authors are agreeing with this hypothesis. Thus, Frost et al. found any difference in $\mathrm{AF}$ rate between diabetic men and women, whereas other ones (Benjamin et al., Nichols et al.) revealed greater risk of AF in women with DM than in male population. In Ruigomez et al. study with $1035 \mathrm{DM}+\mathrm{AF}$ patients comparing with 5000 non-diabetic patients with $\mathrm{AF}$ were found no association between DM and AF occurrence. A large metaanalysis made in 2011 patients with diabetes had a nearly $40 \%$ greater risk of AF comparing to non-diabetic patients (relative risk 1.39, $95 \%$ confidence interval $[\mathrm{CI}] 1.10-1.75 ; \mathrm{P}<0.001$ ) [1]. So influence of DM on AF occurrence and re-occurrence after cardioversion is still a matter of discussion.

\section{CLINICAL CASE}

A 78-year old female was admitted by ambulance in the emergency department of 5 Kharkiv clinical hospital with complains on palpitation, episodic pressing pain in left part of chest, no clear connection with provoking factors; dyspnea on mild physical exertion and labile blood pressure.

\section{ANAMNESIS MORBI}

Patient has a 2-year history of arterial hypertension and atrial fibrillation with an average blood pressure (BP) level of $170 / 100 \mathrm{~mm} \mathrm{Hg}$, which was unsuccessfully ambulatory treated with amiodarone, digoxin, aspirin, spironolactone, and Lisinopril. Hyperglycemia for several years without specific treatment. She was admitted to the hospital following deterioration in her health due to unsuccessful previous therapy.

\section{ANAMNESIS VITAE}

Childhood infections, injuries, tuberculosis, sexually transmitted diseases were denied by patient. Hereditary diseases are not identified. Allergic history is burdened (allergic dermatitis for digoxin).Smoking - denied, not an alcohol abuser. Family history of DM and cardiovascular disease: mother had DM and $\mathrm{AH}$.

\section{OBJECTIVE EXAMINATION}

Consciousness: clear; state: moderate severity; body position: active. Temperature: $36.7^{\circ} \mathrm{C}$. Patient can orientate herself in place, time and personality. Moves with a walker only. Appearance: pale skin, acrocyanosis. Thyroid gland: within normal limits. Musculoskeletal: deformation of hip and knee joints, patient can only walk with support. Obesity II degree (BMI - 35.0). Respiratory rate $-22 / \mathrm{min}$. Lung percussion: no clinically significant changes, resonance. Lung auscultation: weakened breathing in the lower parts of both lungs. Pulse: arrhythmic, 90 bpm; BP $-160 / 80 \mathrm{~mm} \mathrm{Hg}$. Borders of the heart: left border is displaced $2 \mathrm{~cm}$ outwards from the left mid clavicular line. Heart auscultation: heart rate (HR) - 97/min, arrhythmic, atrial fibrillation. Muffled heart tones, accentuation of the second tone on the pulmonary trunk point of auscultation, diffuse systolic murmur in all points with epicenter at the apex of the heart. Abdomen: soft and painless, enlarged due to deposition of adipose tissue. Liver: near the rib edge, no pain on palpation of the right hypochondriac region. Spleen: not palpated. Pasternatsky symptom: negative on both sides. Stool and diuresis: normal. Bilateral pitting edema of lower extremities

\section{LABORATORY AND INSTRUMENTALTESTS}

Complete blood count data showed: high levels of hemoglobin $(152 \mathrm{~g} / \mathrm{l}$ within the normal ranges120-140), red blood cells (5,06 within the normal ranges $3.9-4.7 * 10^{9} / 1$ ) and hematocrit ( $43 \%$ within the normal ranges $34-42 \%$ ).

Urinalysis: microalbuminuria $(0.03 \mathrm{~g} / \mathrm{l})$, hematuria as signs of diabetic nephropathy; leukocyturia ( $1 / 2$ of field), bacteria (many) as chronic pyelonephritis presentation.

In biochemistry analysis data significant were: hyperglycemia $(7.23 \mathrm{mmol} / \mathrm{l})$, hypercreatinemia (94 mmol/l), low GFR $(79,42 \%)$ as confirmation of diabetes mellitus 2 type present 
and its complication diabetic nephropathy. Glycemic profile 5,1 - 5,8 - 5,5 - 10,7 - 4,6 $6,2 \mathrm{mmol} / \mathrm{l}$. Lipid profile showed dyslipidemia with elevated concentrations of total cholesterol till 5.66 (normal ranges $-<5.2 \mathrm{mmol} / \mathrm{l}$ ), lipoproteids of low density till $4,05 \mathrm{mmol} / \mathrm{l}(\mathrm{N}-$ <3.5), lipoproteids of high density till $1,08 \mathrm{mmol} / \mathrm{l} \quad(\mathrm{N}-\geq 0.9)$, index of atherogenicity was 4,24 within normal limits < 3.0. Patient didn't take any constant hypolipidemic therapy before hospitalization.

ECG during admission showed atrial fibrillation, left ventricle (LV) myocardium hypertrophy, alternation of repolarization as ST-depression in V2-V6, I, II - $1 \mathrm{~mm}$.

In our patient chest X-ray was found signs of pulmonary hypertension: enlarged pulmonary arteries enlarged right atrium, elevated cardiac apex due to right ventricular hypertrophy. Enlargement of heart shadow to the left. Sclerotic changes of the aortic arch. Widening of the upper mediastinum to the right side.

Echocardiography made during hospitalization revealed: aorta: d $32,2 \mathrm{~cm}$, sclerotic changes of aortic walls, dilatation of the ascending aorta, fibrosis and calcinosis of aortic valve, aortic regurgitation - I-II degree. Tricuspid valve - regurgitation I-II degree. Pulmonary trunk valve - regurgitation I stage. Pressure in pulmonary trunk is $38,7 \mathrm{~mm} \mathrm{Hg}$ ( $\mathrm{n}$ $<15$ ). Mitral valve - cuspids are moderately thickened, fibrosis and calcinosis, regurgitation II-III degree. Ejection fraction (EF) $-54 \%(\mathrm{~N}$ $-55-78 \%$ ). Contractility function (FC) $-28 \%$ ( $\mathrm{N}-28-44 \%)$. Left Ventricle: FDD - 48,9 mm $(\mathrm{N}-35-55 \mathrm{~mm})$. FSD - 35,1 mm ( $-23-$ $38 \mathrm{~mm}$ ). Posterior wall thickness in systole $16,6 \mathrm{~mm}$ ( $\mathrm{N}-6-11 \mathrm{~mm})$. Intraventricular septum size in diastole- $16,2 \mathrm{~mm}(6-11 \mathrm{~mm})$.

Right Ventricle: diameter - 31,9 mm (N 9-26 mm). Wall thickness $-6,9 \mathrm{~mm}(\mathrm{~N}-3-$ $6 \mathrm{~mm}$ ). Left atrium - enlarged $-44,1 \mathrm{~mm}$ in diameter $(\mathrm{N}-$ till $38 \mathrm{~mm})$. Right atrium enlarged, 48,8 mm ( $\mathrm{N}-21-37)$. Intraatrial septum - not changed, no defects. Conclusion: Atrial fibrillation, sclerotic changes of aorta, dilatation of the ascending aorta. Aortic regurgitation I-II degree. Mitral regurgitation II-III degree. Tricuspid regurgitation II degree. Pulmonary trunk regurgitation I stage. Moderate dilation of right and left atriums. Myocardial hypertrophy of both ventricles. Pulmonary hypertension II stage.
Abdominal ultrasound was performed also: Diffuse change of liver parenchyma with mild hepatomegaly. Congestive process in portal vein system. Cholestasis of gall bladder. Chronic non-calculous cholecystitis. Diffuse changes of pancreatic parenchyma. Kidney calcinosis. Diffuse changes of both kidneys parenchyma. Right kidney pyeloectasia and cyst.

\section{FINAL DIAGNOSIS}

Coronary artery disease: stable angina III functional class. Arterial hypertension stage 3, III degree. Permanent atrial fibrillation. CHA2DS2-VASc score 5 points. HAS-BLED Score 2 points. ATRIA Bleeding Risk Score 3 points. Chronic heart failure stage IIIC with preserved ejection fraction, III functional class by NYHA. Type 2 diabetes mellitus, complicated by diabetic nephropathy stage 2 (incipient nephropathy). Chronic Kidney Disease stage 2 (GFR - $79.42 \mathrm{~mL} / \mathrm{min}$ ). Chronic non calculous cholecystitis. Chronic pancreatitis. Right kidney cyst. Deforming bilateral gonarthritis and coxarthritis.

\section{TREATMENT RECEIVED IN HOSPITAL}

Clopidogrel $75 \mathrm{mg} 1$ time/day, nebivolol $5 \mathrm{mg} 1$ time/day, valsartan $80 \mathrm{mg} 1$ time/day, atorvastatin $80 \mathrm{mg} 1 \mathrm{time} /$ day, torasemide $10 \mathrm{mg} 1 \mathrm{time} /$ day, cardioarginin $5 \mathrm{ml}$ IV 1 time/day for 5 days, metformine initial $500 \mathrm{mg}$ PO every $12 \mathrm{hr}$, after adjustment: $1500 \mathrm{mg} /$ day.

\section{RECOMMENDATIONS}

Despite good progress in the management of patients with atrial fibrillation, it remains one of the major causes of stroke, heart failure, sudden death, and cardiovascular morbidity in the world. Reflecting the multidisciplinary input into the management of patients with $\mathrm{AF}$, especially in patients with diabetes mellitus, for our patient could be recommended:

1. Diabetes is a risk factor of $\mathrm{AF}$ complications. Prolongation of diabetes duration in patients with $\mathrm{AF}$, connected with risk of thrombo-embolism, anticoagulation therapy-related bleeding [5]. Treatment with metformin [7] seems to be associated with a decreased long-term risk of $\mathrm{AF}$ in diabetic patients and may even be associated with a lower long-term stroke risk [8], also for patient with established atherosclerotic cardiovascular disease therapy should begin with lifestyle 
management and metformin ${ }_{+}+$in future empagliflozin and liraglutide if needed proven to reduce major adverse cardiovascular events). Behavioral therapy designed to achieve $>5 \%$ weight loss should be prescribed. With the body mass index (BMI) progression increases the risk for AF. Predisposing factors for obese patients may are LV diastolic dysfunction, increased sympathetic activity and inflammative changes, and abnormal atrial fatty infiltration [9]. Management of risk factors along with weight loss recommendations will be useful in reducing of $\mathrm{AF}$ burden and symptoms [10].

2. Mitral regurgitation (MR) as others valvular heart disease is independently associated with incident AF [10] and associated with severe LV dysfunction due to secondary MR in patients with ischemic heart disease (in our patient's case). Chronic severe secondary MR and aortic regurgitation present in our patient lead to volume overload with LV function decompensation and prognosis worsening [11].

3. In patients with heart failure with preserved ejection fraction (HFpEF) in our patient with $\mathrm{AF}$ it's hard to separate symptoms of $\mathrm{HF}$ from symptoms caused by $\mathrm{AF}$ appearance itself. In this case will be useful echocardiography and natriuretic peptide levels as evidence of relevant structural heart disease. The management of patients with $\mathrm{AF}$ and concomitant HFpEF should focus on the control of fluid balance and concomitant conditions such as hypertension and myocardial ischemia [12-13]. In adults with HFpEF who present with symptoms of volume overload, diuretics should be prescribed to control hypertension. Adults with HFpEF and persistent hypertension after management of volume overload should be prescribed angiotensin converting enzyme (ACE) inhibitors or angiotensin receptors blockers (ARBs) and beta blockers titrated for treatment goal of systolic BP level below than $130 \mathrm{~mm} \mathrm{Hg}$ [14].

4. Uncontrolled high blood pressure induces increased risk of stroke and bleeding events and sinus rhythm conversion to AF. That's why, strict blood pressure control should be an integral part of the AF patients' management [12]. Despite the fact that ACE inhibitors or ARBs have a beneficial effect on the occurrence of overt AF, but in patients with established AF, but without LV dysfunction (our patient) or heart failure, ARBs do not prevent recurrent $\mathrm{AF}$ better than placebo. Further structural remodeling and sinus rhythm conversion to AF can be prevented by inhibition of the renin-angiotensin-aldosterone system [10]. In adults with DM and hypertension, antihypertensive drug treatment should be initiated at a BP of $130 / 80 \mathrm{~mm} \mathrm{Hg}$ or higher with a treatment DBP: goal of less than 130/80 mm Hg. ACE inhibitors and ARBs have the best efficacy among the drug classes on urinary albumin excretion [14].

5. The CHA2DS2-VASc score is recommended for stroke risk prediction in patients with $\mathrm{AF}$ by latest $\mathrm{AF}$ management guidelines [10]. Vitamin K antagonists (VKA) therapy are useful in AF for stroke, systemic embolism, myocardial infarction, and cardiac death prevention, effectiveness of this therapeutic strategy is higher than single or dual antiplatelet therapy with aspirin and clopidogrel (annual risk of $5.6 \%$ for aspirin and clopidogrel vs. $3.9 \%$ with VKA therapy). Also VKA therapy has decreased bleeding risk, comparing with dual antiplatelet therapy. That's why, antiplatelet therapy shouldn't be recommended for stroke prevention in AF patients [13].

6. Rate control is an integral part of the management of AF patients, and is often sufficient to improve AF-related symptoms. The aim of antiarrhythmic drug therapy is improvement in AF-related symptoms. Amiodarone wouldn't be a drug of choice for our patient due to increased risk of myopathy with statins and potentiating of VKAs therapy. Propafenone is contra-indicated in ischemic heart disease. Sotalol is contra-indicated in the presence of significant LV hypertrophy, systolic heart failure. Digoxin is proarrhythmic and can aggravate heart failure. Nondihydropyridine calcium channel blockers are contra-indicated in LV failure with pulmonary congestion. Betablockers with ability to improve symptomatic and functional heart conditions through the rate control, lack of harm (from investigations published), and good tolerability in all ages [9] are useful as first-line rate control drugs in $\mathrm{AF}$ patients.

\section{CONCLUSIONS}

Atrial fibrillation and diabetes mellitus are very common comorbidities and with high expectance they will co-exist together in the future because of the both conditions prevalence especially in older patients group. Therefore, establishing of the most effective 
and safe treatment it is very important to the subpopulation of patients with AF and DM. New studies with larger numbers of patients from different age and rage groups with diabetes and $\mathrm{AF}$ are needed to investigate the mechanisms of this relationship and all possible therapeutic approaches in order to determine the best possible individual management of both conditions.

\section{REFERENCES}

1. Tadic M. Type 2 diabetes mellitus and atrial fibrillation: From mechanisms to clinical practice / M. Tadic, C. Cuspidic // Archives of Cardiovascular Diseases. -2015. - Vol.108 (4). - p. 269-276.

2. Martin-Timon. Type 2 diabetes and cardiovascular disease: have all risk factors the same strength? / Martin-Timon, C. Sevillano-Collantes, A. Segura-Galindo, F. J. Del Canizo-Gomez // World J Diabetes. 2014. - No. 5. - p. 444-470.

3. Zhang Q. Diabetes mellitus and atrial remodeling: mechanisms and potential upstream therapies / Q. Zhang, T. Liu, C.Y. Ng, G. Li // Cardiovasc Ther. - 2014. - No. 32. - p. 233-4.

4. Chao T.F. Atrial substrate properties and outcome of catheter ablation in patients with paroxysmal atrial fibrillation associated with diabetes mellitus or impaired fasting glucose / T. F. Chao, K. Suenari, S. L. Chang, et al. // Am J Cardiol. - 2010. - No. 106. - p. 1615-1620.

5. Kamenov Z.A. Diabetic autonomic neuropathy / Z. A. Kamenov, L. D. Traykov // Adv Exp Med Biol. 2012. - No. 771. - p. 176-193.

6. Otake H. Influences of autonomic nervous system on atrial arrhythmogenic substrates and the incidence of atrial fibrillation in diabetic heart / H. Otake, H. Suzuki, T. Honda, Y. Maruyama // Int Heart J.- 2009. No. 50. - p. 627-641.

7. Chang S. H., Wu L. S., Chiou M. J., Liu J. R., Yu K. H., Kuo C. F., Wen M. S., Chen W. J., Yeh Y. H., See L. C. Association of metformin with lower atrial fibrillation risk among patients with type 2 diabetes mellitus: a population-based dynamic cohort and in vitro studies. Cardiovasc Diabetol 2014; 13: 123.

8. Fatemi O., Yuriditsky E., Tsioufis C., Tsachris D., Morgan T., Basile J., Bigger T., Cushman W., Goff D., Soliman E. Z., Thomas A., Papademetriou V. Impact of intensive glycemic control on the incidence of atrial fibrillation and associated cardiovascular outcomes in patients with type 2 diabetes mellitus (from the Action to Control Cardiovascular Risk in Diabetes Study). Am J Cardiol 2014; 114: 1217-1222.

9. Overvad T. F., Rasmussen L. H., Skjoth F., Overvad K., Lip G. Y., Larsen T. B. Body mass index and adverse events in patients with incident atrial fibrillation. Am J Med 2013; 126:640.e649-617.

10. 2016 ESC Guidelines for the management of atrial fibrillation developed in collaboration with EACTS / Paulus Kirchhof, Stefano Benussi, Anders Ahlsson et al. //European Heart Journal. - 2016. doi:10.1093/eurheartj/ehw210.

11. 2017 AHA/ACC Focused Update of the 2014 AHA/ACC Guideline for the Management of Patients With Valvular Heart Disease/ [B. Ibanez, S. James, S. Agewall, et al.] // Circulation. - 2017. - No. 1. - p. 1-57.

12. Manolis A. J. Hypertension and atrial fibrillation: diagnostic approach, prevention and treatment. Position paper of the Working Group 'Hypertension Arrhythmias and Thrombosis' of the European Society of Hypertension. / A. J. Manolis, E. A. Rosei, A. Coca, et al. // J Hypertens. - 2012. - No. 30. - p. 239-252.

13. Connolly S. Clopidogrel plus aspirin versus oral anticoagulation for atrial fibrillation in the Atrial fibrillation Clopidogrel Trial with Irbesartan for prevention of Vascular Events (ACTIVE W): a randomised controlled trial. / S. Connolly, J. Pogue, R. Hart, et al. // Lancet. - 2006. - No. 367. - p. 19031912.

14. 2017 ACC/AHA/AAPA/ABC/ACPM/AGS/APhA/ASH/ASPC/NMA/PCNA Guideline for the Prevention, Detection, Evaluation, and Management of High Blood Pressure in Adults / Paul K. Whelton, Robert M. Carey, Wilbert S. Aronow, et al. // JACC. - 2017. - doi : 10.1016/j.jacc.2017.11.006. 